\title{
Clinical and laboratorial evaluation of dogs with cutaneous lymphoma treated with lomustine
}

\author{
Avaliação clínica e laboratorial de cães com linfoma cutâneo tratados com lomustina \\ Amanda Resende DUARTE'; Jéssica de Assis MARQUES ${ }^{1}$; Fabíola Soares ZAHN'; Luiz Henrique de \\ Araújo MACHADO ${ }^{1}$
}

${ }^{1}$ Universidade Estadual Paulista “Júlio de Mesquita Filho", Faculdade de Medicina Veterinária e Zootecnia, Botucatu - SP, Brazil

\begin{abstract}
The aim of this prospective study was to evaluate the clinical response of dogs with cutaneous lymphoma treated with lomustine (CCNU) and to identify possible adverse effects and toxicity during treatment. Fifteen dogs, seven females and eight males aged between five and 17 years old, diagnosed with cutaneous lymphoma by histopathological analysis were selected and treated with lomustine at $90 \mathrm{mg} / \mathrm{m}^{2}$ every three weeks. Monitoring was carried out and consisted of the assessment of laboratory hematology and serum chemistry before and during treatment. Partial response was observed in 53.3\% of the animals. None of the animals achieved a complete response and seven dogs (46.6\%) had progressive disease. The median survival time was 22 days. The major hematological and biochemical changes found after therapy were leukopenia (73.3\%), thrombocytopenia (60\%) and anemia (46.1\%). Renal and liver toxicity was observed in $40 \%$ and $73.3 \%$ of dogs, respectively. Hematocrit, total protein, leukocyte count, neutrophil count, serum creatinine, ALT, GGT, alkaline phosphatase and urine specific gravity were affected during therapy. The use of lomustine as a monotherapy in the treatment of canine cutaneous lymphoma was effective; however, adverse effects occurred and compromised the quality of life of the majority of dogs in this study. Therefore, lower doses of lomustine should be considered in future studies.
\end{abstract}

Keywords: CCNU. Cutaneous lymphoma. Dogs. Oncology. Adverse effects.

\section{Resumo}

O objetivo deste estudo prospectivo foi avaliar a resposta clínica de cães com linfoma cutâneo tratados com lomustina (CCNU) e identificar possíveis efeitos adversos e toxicidade durante o tratamento. Quinze cães, sendo 7 fêmeas e 8 machos, com idades entre 5 e 17 anos diagnosticados com linfoma cutâneo por avaliação histopatológica foram selecionados e tratados com lomustina na dose de $90 \mathrm{mg} / \mathrm{m} 2$ a cada três semanas. Os cães foram monitorados por avaliação hematológica e bioquímica sérica antes e durante o tratamento. A resposta parcial foi observada em $53,3 \%$ dos animais. Nenhum dos animais apresentou resposta completa e sete animais (46,6\%) apresentaram progressão da doença. O tempo médio de sobrevida foi de 22 dias. As principais alterações hematológicas e bioquímicas observadas após o tratamento foram leucopenia (73,3\%), trombocitopenia (60\%) e anemia (46,1\%). Sinais de toxicidade renal e hepática foram observados em $40 \%$ e $73,3 \%$ dos cães, respectivamente. Durante o tratamento foram afetados os parâmetros hematócrito, proteínas séricas totais, contagem de leucócitos, contagem de neutrófilos, creatinina sérica, ALT, GGT, fosfatase alcalina e densidade urinária. O uso de lomustina como monoterapia no tratamento do linfoma cutâneo canino foi efetivo; entretanto, efeitos adversos ocorreram e comprometeram a qualidade de vida da maioria dos animais neste estudo. Assim, sugere-se que doses mais baixas de lomustina sejam consideradas em estudos futuros.

Palavras-chave: CCNU. Linfoma cutâneo. Cães. Oncologia. Efeitos adversos.

\section{Correspondence to:}

Luiz Henrique de Araujo Machado

Universidade Estadual Paulista "Júlio de Mesquita Filho", Faculdade de Medicina Veterinária e Zootecnia, Departamento de Clínica Veterinária

Distrito de Rubião Jr, s/n - Cx Postal 560

CEP 18618-070, Botucatu, SP, Brazil

e-mail: henrique@fmvz.unesp.br

Received: 06/09/2014

Approved: 06/02/2016 


\section{Introduction}

Skin is considered the most common site for the onset of tumors in dogs, representing approximately $1 / 3$ of all cases of neoplasms in this species (HAUCK, 2013).

Cutaneous lymphoma (CL) is considered a rare form of canine lymphoma, representing only $1 \%$ of canine neoplasms in dogs (FONTAINE et al., 2009). It is characterized by $\mathrm{T}$ or $\mathrm{B}$ neoplastic lymph cells proliferation and infiltration in the epidermis, dermis and cutaneous annexes (FONTAINE et al., 2010).

Although its etiology is unknown, cutaneous lymphoma has been associated with chemical compounds, viral infections and chronic skin inflammation (MOORE; OLIVRY, 1994; FOURNELFLEURY et al., 2002; FONTAINE et al., 2009) and it occurs more frequently in elder dogs (average nine to 10 years-old), with no predilection for gender (MOORE; OLIVRY, 1994). According to the literature, there is a predisposition in Cocker Spaniels and Boxers (FONTAINE et al., 2009).

Canine cutaneous lymphoma represents a group of heterogeneous clinical presentations that may be histologically classified as cutaneous epitheliotropic lymphoma (CEL) and non-epitheliotropic lymphoma (NEL), with the CEL type being more frequently described in veterinary medicine. The main clinical signs are: exfoliative erythema, plaques, nodules, ulceration of oral mucosa and the mucocutaneous form (FONTAINE et al., 2009). An important variability on clinical behavior of the disease is observed - from an indolent clinical course to a rapidly fatal systemic disease, with three to six months' survival time for the advanced disease (HEADING et al., 2011). In most cases, cutaneous lymphoma is diagnosed in advanced stages, with multifocal lesions and dissemination to other organs, making systemic chemotherapy more suitable (LORIMIER, 2006).

The use of lomustine chemotherapy (CCNU), an alkylating agent of the nitrosurea class, has been reported in several neoplasms such as cerebral tumors, mast cell tumors, relapsing lymphoma and histiocytic sarcoma (HEADING et al., 2011). Its use alone or in combination with other chemotherapeutic drugs in cases of canine cutaneous lymphoma has been widely studied, both on initial approach and on relapsing cases. Willians et al. (2006) and Risbon et al. (2006) reported more than $70 \%$ of therapeutic response with the use of CCNU in cases of cutaneous lymphoma in dogs. Satisfactory results associated with a relative low cost and practical administration make lomustine a promising therapeutic choice. On the other hand, the toxicological potential of this drug has been evaluated and its use has been associated with side effects. Myelosuppression is the most frequent side effect, followed by gastrointestinal signs (KRISTAL et al., 2004; HEADING et al., 2011). Nephrotoxicity and hepatotoxicity are also described, shortening the survival length of treated animals.

The aims of the present study were to characterize the canine population diagnosed with cutaneous lymphoma, to evaluate the therapeutic response with lomustine therapy; and to describe the side effects associated with this chemotherapeutic agent. Also, the authors tried to establish any clinical or laboratorial parameters that could be correlated with prognosis.

\section{Material and Methods}

The dogs were selected among cases attended at the Veterinary Hospital at São Paulo State University in Botucatu and all the owners signed a consent form before having their animals treated with lomustine. Dogs were eligible for inclusion in the study if they had a histopathological diagnosis of cutaneous lymphoma. Exclusion criteria included patients treated concurrently with other chemotherapy drugs or corticosteroids while on lomustine therapy, and insufficient patient follow-up.

After the confirmation of the diagnosis, therapy with lomustine (Citostal, Bristol) at $90 \mathrm{mg} / \mathrm{m}^{2} \mathrm{PO}$, as well as the clinical evaluation, was initiated and repeated every three weeks, except when the animals presented with the total white blood cell count less 
than $3,000 / \mu \mathrm{L}$ and/or with platelet count less than $50,000 / \mu \mathrm{L}$.

All the animals were monitored for the evolution of therapy, both during induction of remission and maintenance. Clinical follow-up was based on macroscopic evaluation of the lesions. According to the size of the nodules, therapy response was determined by the following criteria: 1) stable disease ( $\mathrm{SD}$ - 0\% tumor decrease); 2) partial remission (PR $50 \%$ tumor decrease); 3 ) complete remission (CR $100 \%$ tumor decrease); and 4) progressive disease (further tumor increase).

Toxicosis associated with lomustine therapy was graded according to the Veterinary Cooperative Oncology Group Common Terminology Criteria for Adverse Events criteria (VETERINARY, 2011). Laboratory follow-up was done before the beginning of therapy and during the whole course of chemotherapy treatment. It consisted in monitoring the complete blood count (red blood cells, white blood cells and platelets), serum biochemistry (urea, creatinine, ALT, ALP, GGT, total protein, albumin, globulin) and urinary parameters (density, $\mathrm{pH}$ and protein). The reference values used were those proposed by Kaneko et al. (2008). Additional tests, such as thoracic $\mathrm{x}$-rays and abdominal ultrasound, were performed to prove that the lymphoma was only confined to the skin. Immunohistochemistry was performed in all tumor samples. All animals were diagnosed with $\mathrm{T}$-cell cutaneous lymphoma.

All clinical and laboratory parameters were assessed on Day 1, the first day of treatment (M1) and before each administration of chemotherapy, every three weeks. The degree of increase or decrease of the evaluated parameters (hematology, serum biochemistry and urinalysis) was based on the highest or lowest recorded change (M2). According to each animal's particular needs, additional laboratory tests were performed when deemed indicated by the clinician's discretion.

Based on data collected at the initial examination of all animals, Shapiro-Wilk normality test was applied and demonstrated that the parameters are not normally distributed. For this reason, statistical analysis was based on non-parametric methods. To check the influence of the treatment on several parameters evaluated, Mood Median Test was used and $95 \%$ of significance was adopted. Pearson test was used to evaluate the correlation between hematological, biochemical and urinary parameters and survival time. For this test, a critical value of 0.514 was adopted. The relationship between the probability of survival and time was verified by Kaplan-Meier test, and 95\% significance was adopted.

\section{Results and Discussion}

For the present study, 15 dogs with cutaneous lymphoma were selected. Of these, 53.3\% (8/15) were mongrel dogs and 46.7\% (7/15) were from different breeds $14.3 \%$ (1/7) for each of the following breeds: Border Collie, Boxer, Dalmatian, Labrador Retriever, Lhasa Apso, American Pit Bull Terrier and Poodle. Among those breeds, only the Boxer was previously described as predisposed to canine lymphoma. However, evaluation of racial predisposition is debatable, since the reported cases of cutaneous lymphoma come from many different countries and regions, and in most cases, the distribution of breeds in each place is not known (FONTAINE et al., 2009).

The mean age at diagnosis in the present study was $10.7 \pm 4$ years, while the median was 8.9 years, and as for gender, $53.3 \%$ were males and $47.7 \%$ females. In a total of 72 previously reported cases, the mean age at the moment of diagnosis was 8.6 years (FONTAINE et al., 2009), which demonstrates that dogs affected by cutaneous lymphoma are middle aged and older.

Regarding the histopathological evaluation, 13 samples were classified as non-epitheliotropic cutaneous lymphoma (NEL) and two as cutaneous epitheliotropic lymphoma (CEL). The CEL type is reported to be the most common form of cutaneous lymphoma in dogs (MOORE; OLIVRY, 1994); however, in the present study, the NEL type was predominant, representing $86.6 \%$ (13/15) of evaluated 
animals. The high incidence of NEL may be due to a limited number of cases found in our study.

Among the cases included in this study, 53.3\% $(8 / 15)$ of the animals responded to lomustine therapy with partial remissions, there were no complete remissions, and seven (46.6\%) dogs had progressive disease. The assessment of therapeutic response in cutaneous lymphoma can be quite subjective, because since all the animals had diffusely distributed lesions, analysis of each one of the lesions may become impossible. However, the clinical improvement or reduction of pre-existing lesions were considered a parameter to evaluate the response to treatment.

The mean cumulative dose of CCNU chemotherapy was $204 \mathrm{mg} / \mathrm{m}^{2}$ and average number of cycles required for clinical remission was two cycles, ranging from one to five cycles.

The overall rate of response to treatment was $53.3 \%$, lower than those described by Willians et al. (2006) and Risbon et al. (2006), using CCNU $60 \mathrm{mg} / \mathrm{m}^{2}$ every three weeks $(78 \%$ and $80 \%$, respectively). Although a direct comparison with historical studies could not be made, the lower response to therapy noted in the present study should be considered carefully because, in those studies, there was previous sensitization or combination with other antineoplastic agents, such as glucocorticoids, which are known for leading to initial disease remission.

According to the results provided by Kaplan-Meier test (Figure 1), the median survival time, representing $50 \%$ of the studied population, was 22 days, which is lower than that reported by Willians et al. (2006). The short survival time of our population of dogs may be related to the late diagnosis of the disease. These animals had already gone through previous unsuccessful skin treatments and presented a more advanced clinical stage, an aspect not pointed out on studied reports.

The predominance of dogs with nonepitheliotropic cutaneous lymphoma may also explain the shorter survival time and lower rate of therapeutic response in this study, since in studies conducted by

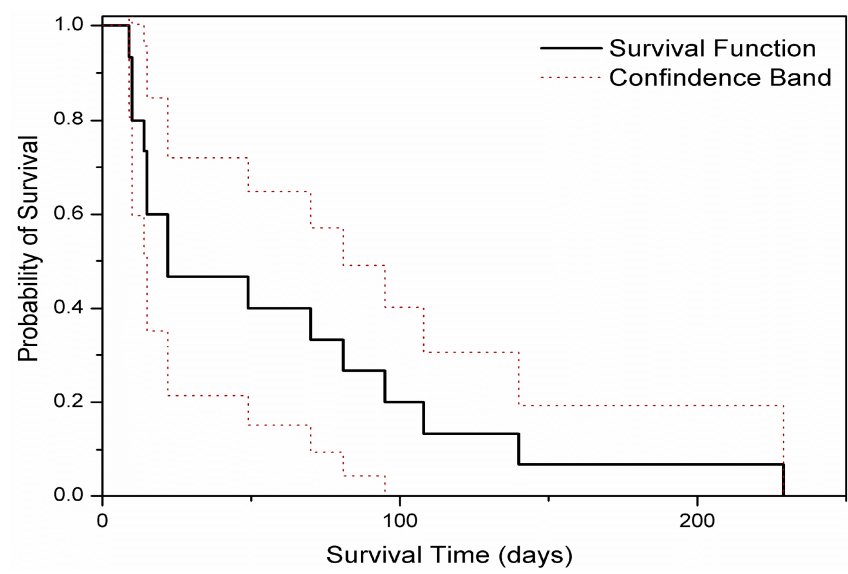

Figure 1 - Kaplan-Meier curve for probability of survival versus survival time (days) of dogs with cutaneous lymphoma treated with lomustine.

Risbon et al. (2006) and Willians et al. (2006) all dogs had epitheliotropic cutaneous lymphoma. This difference may suggest that the type of cutaneous lymphoma could influence the therapeutic response and that the NEL type may be associated with a worse prognosis when compared to the CEL type.

The use of lomustine can lead to different presentations of toxicity. The first indication of toxicity observed when a dose of $90 \mathrm{mg} / \mathrm{m}^{2}$ is used is myelosuppression, especially neutropenia, seven days after the administration of the drug (KRISTAL et al., 2004; RISBON et al., 2006). It is known that lomustine, like other chemotherapeutic agents, acts by destroying cells in a nonspecific manner, both neoplastic and normal cells, in particular fast-growing cells, such as gastrointestinal and immune system cells (ALMEIDA et al., 2005). Ninety-three percent $(14 / 15)$ of the evaluated animals showed a reduction in the WBC count (especially neutropenia) from M1 to M2. Twenty-six percent of the animals (4/15) presented significant leukopenia (mean 465 cells/uL, VCOG-CTCAE grade 4); 26\% (4/15) presented moderate leukopenia (mean 1,662 cells/uL, VCOGCTCAE grade 1) and 20\% (3/15) presented mild leukopenia (mean 4,700 cells/uL, VCOG-CTCAE grade 1 ) at end of chemotherapy. One animal showed a decreased total leukocyte count, but remained within the reference range. Although leukopenia makes the animals highly susceptible to infections and 
sepsis, no fever or other clinical signs of sepsis were observed in the evaluated animals.

Nonregenerative anemia was detected in $86.6 \%$ (13/15) of studied dogs; $53.8 \%$ (7/15) were diagnosed with nonregenerative anemia before chemotherapy and $46.1 \%(6 / 15)$ after treatment with lomustine. Mean values of hemoglobin and hematocrit at the end of chemotherapy were $9.4 \mathrm{~g} / \mathrm{dl}$ (VCOG-CTCAE grade 2) and 27\% (VCOG-CTCAE grade 2) respectively, indicating anemia. However, blood transfusion was not necessary in any individual case. Thrombocytopenia was detected in 60\% (9/15) of cases after the administration of lomustine. Mean platelet count at M2 was 154,062 platelets/uL (VCOGCTCAE grade 1), evidencing thrombocytopenia, although hemorrhagic episodes were not observed.

Myelosuppression observed in this study was quite evident after several sessions of chemotherapy, suggesting a cumulative toxicity of lomustine in these animals. This may be reversed or alleviated by reducing the dose of the chemotherapeutic agent and providing appropriate supportive treatment. Rassnick et al. (1999) evaluated the effects of lomustine in dogs with mast cell tumors and reported that $41 \%(7 / 17)$ of the evaluated animals developed leukopenia $(<1000$ total leukocytes VCOG-CTCAE grade 3-4), but only a few showed signs of systemic infection.

Gastrointestinal toxicity was an important finding in $60 \%$ of dogs. Anorexia (VCOG-CTCAE grade 2) was the clinical sign most frequently described by the owners $(83.3 \%)$, followed by vomiting (16.6\%, VCOGCTCAE grade 1) and diarrhea (8.3\%, VCOG-CTCAE grade 2). Anorexia is a nonspecific common clinical symptom in cancer patients, probably associated with a natural process of the disease and anorexigenic substances produced by the tumor or by the body itself in response to the neoplastic process (SILVIA, 2006). Nevertheless, since the clinical signs were only observed after the administration of lomustine, we may conclude that anorexia in these cases probably was not associated with a paraneoplastic syndrome.
Hepatotoxicity caused by the use of lomustine is recognized by increased serum liver enzymes, especially ALT and hypoalbuminemia (KRISTAL et al., 2004). When values obtained in serum biochemistry at M2 were compared to those obtained at M1, 93.3\% (14/15) of evaluated animals presented increased levels of ALT (VCOG-CTCAE grade 2), $86.6 \%(13 / 15)$ presented increased levels of ALP (VCOG-CTCAE grade 1), and $33.3 \%$ (5/15) presented increased levels of GGT (VCOG-CTCAE not determined). These three parameters were significantly different between moments (table 1). This finding supports the results obtained by Kristal et al. (2004) and Hosoya et al. (2009) that the use of CCNU can lead to hepatocellular injury and cholestasis.

Hosoya et al. (2009) observed in their study that one of the animals presenting clinical liver disease did not present increased levels of ALT, suggesting that this parameter should not be assessed in isolation as a marker of hepatotoxicity but in conjunction with other biochemical analyzes, such as the determination of bile acids and bilirubin. In the present study, no animal showed clinical signs of active liver disease or liver failure; however, recent studies evaluating the toxicity of lomustine reported the occurrence of liver failure and death in 1.2\% (HEADING et al., 2011) to $4.0 \%$ of patients (KRISTAL et al., 2004). We suggest that the outcome of liver evaluation may consider a subclinical hepatotoxicity in these animals and that critical monitoring may be required. Concurrent use of an association of Silymarin and Sadenosylmethionine to minimize increased liver enzyme activity in dogs receiving CCNU is supported by the study of Skorupski et al. (2011).

Evidences of renal toxicity, such as azotemia, polyuria, and polydipsia, are also reported, but usually to a lesser degree (HEADING et al., 2011; FLORY et al., 2008). In this study, although there were no complaints of clinical symptoms related to renal failure, increased values of urea (VCOG-CTCAE grade 1 ) and creatinine (VCOG-CTCAE grade 2) were 
observed in $66.6 \%(10 / 15)$ and $40 \%(6 / 15)$ of the evaluated animals at $\mathrm{M} 2$, respectively. Urinary density was also evaluated during therapy and was decreased (VCOG-CTCAE not determined) in 93.3\% (14/15) of the animals, reaching isosthenuria in two cases. All animals exhibited proteinuria and $53.3 \%(8 / 15)$ of the animals presented values of urinary protein above 100 $\mathrm{mg} / \mathrm{dl}$; cellularity was observed in two of those animals (25\%), which may have influenced the interpretation of the urinary protein levels. According to Polzini (2007), proteinuria may be present in the initial stage of renal disease, even before the development of azotemia. These results evidenced the nephrotoxic potential of lomustine therapy, with decreased urinary density, which is known to be the first clinical evidence of renal tubular injury. In association with decreased urinary density, persistent proteinuria was also verified; this parameter is considered an indicator of glomerular injury and its elevation reflects progression of the injury (JACOB et al., 2005).

Table 1 - Median values for hematologic, biochemical and urinary parameters of 15 dogs with canine cutaneous lymphoma, obtained before (M1) and after (M2) chemotherapy with lomustine Botucatu, SP - 2012

\begin{tabular}{cccc}
\hline Parameters & M1 & M2 & P value \\
\hline Red Blood Cells $\left(10^{6} / \mu \mathrm{L}\right)$ & $\mathbf{5 . 5 1}^{\mathbf{a}}$ & $\mathbf{3 . 8 3}^{\mathbf{b}}$ & $\mathbf{0 . 0 4 9}$ \\
Hemoglobin $(\mathrm{g} / \mathrm{dL})$ & $\mathbf{1 2 . 9 5}^{\mathbf{a}}$ & $\mathbf{9 . 4}^{\mathbf{b}}$ & $\mathbf{0 . 0 0 7}$ \\
Hematocrit $(\%)$ & $\mathbf{3 8 . 5}^{\mathbf{a}}$ & $\mathbf{2 7}^{\mathbf{b}}$ & $\mathbf{0 . 0 2 3}$ \\
Total Protein $(\mathrm{g} / \mathrm{dL})$ & $\mathbf{8 . 2}^{\mathbf{a}}$ & $\mathbf{6 . 7 b}^{\mathbf{b}}$ & $\mathbf{0 . 0 2 1}$ \\
Platelets $(/ \mu \mathrm{L})$ & 154000 & 154062 & 1 \\
White blood cells $(/ \mu \mathrm{L})$ & $\mathbf{9 3 0 0}^{\mathbf{a}}$ & $\mathbf{1 8 9 0}^{\mathbf{b}}$ & $\mathbf{0 . 0 0 2}$ \\
Bands $(/ \mu \mathrm{L})$ & 0 & 0 & 0.345 \\
Segmented $(/ \mu \mathrm{L})$ & $\mathbf{5 4 5 0}^{\mathbf{a}}$ & $\mathbf{2 3 0 0}^{\mathbf{b}}$ & $\mathbf{0 . 0 1 8}$ \\
Lymphocytes $(/ \mu \mathrm{L})$ & 600 & 210 & 0.431 \\
Eosinophils $(/ \mu \mathrm{L})$ & 300 & 0 & 0.224 \\
Basophils $(/ \mu \mathrm{L})$ & 0 & 0 & 0.172 \\
Monocytes $(/ \mu \mathrm{L})$ & 550 & 250 & 0.431 \\
Urea $(\mathrm{mg} / \mathrm{dL})$ & 39.5 & 79 & 0.023 \\
Creatinine $(\mathrm{mg} / \mathrm{dL})$ & 0.90 & 1.55 & 0.058 \\
ALT $(\mathrm{UI} / \mathrm{L})$ & $\mathbf{5 4}^{\mathbf{a}}$ & $\mathbf{2 4 2 . 0 5}$ & $\mathbf{0 . 0 0 0 1 5}$ \\
ALP $(\mathrm{UI} / \mathrm{L})$ & $\mathbf{1 0 8 . 5}^{\mathbf{b}}$ & $\mathbf{3 8 1 . 9 5}$ & $\mathbf{0 . 0 2 3}$ \\
GGT $(\mathrm{UI} / \mathrm{L})$ & $\mathbf{3}^{\mathbf{b}}$ & $\mathbf{6 . 1 5}^{\mathbf{b}}$ & $\mathbf{0 . 0 0 2}$ \\
Albumin $(\mathrm{g} / \mathrm{dL})$ & 2.3 & 2.1 & 0.058 \\
Globulin $(\mathrm{g} / \mathrm{dL})$ & 5.7 & 4.9 & 0.130 \\
Urinary Density & $\mathbf{1 0 2 6}^{\mathbf{b}}$ & $\mathbf{1 0 1 5}^{\mathbf{b}}$ & $\mathbf{0 . 0 0 0 1 3}$ \\
Urinary $\mathrm{pH}$ & 6.5 & 6.35 & 0.308 \\
Urinary protein $(\mathrm{mg} / \mathrm{dL})$ & 30 & 100 & 0.053 \\
\hline
\end{tabular}

${ }^{\mathrm{ab}}$ Different letters in a row indicate significant difference $(\mathrm{P} \leq 0.05)$ 
Significant differences in serum levels of urea and urine density were observed between M1 and M2, thus suggesting the potential deleterious effects of the use of lomustine in the evaluated dogs (Table 1). An important fact to consider is that some of these animals had become anorexic, with episodes of vomiting and diarrhea during chemotherapy, and this may have led to the development of dehydration and pre-renal azotemia leading to an increase in urine density, especially in the first urine of the day. However, these clinical aspects were not consistent with alterations in urine density.

The risk of toxicity influences the dosage and frequency of administration of lomustine. Previous studies suggest that the adverse effects of CCNU are dose-dependent, so its use at lower doses would induce fewer side effects and greater reversibility of clinical signs (KRISTAL et al., 2004). Risbon et al. (2006) used lower dosages than that used in the present study (overall median starting dose of 60 $\mathrm{mg} / \mathrm{m}^{2}$ ) and obtained higher rates of response to treatment $(82.6 \%)$. This indicates that higher doses may not achieve the desired cytotoxic effect since many dogs need to have their lomustine treatment postponed due abnormalities encountered in the bloodwork. Higher doses may also cause even more injury or shorten the animals' lifetime. Because lomustine is offered in pills and, thus, is an outpatient drug, it may be erroneously assumed that $\mathrm{CCNU}$ is not as harmful as other chemotherapy agents and, therefore, it is important that both its desired and undesired effects be deeply evaluated. The goals of chemotherapy are to induce cytotoxicity with tolerable side effects.

Results obtained in this study can corroborate the findings of literature, as $\mathrm{RBC}$, hemoglobin, hematocrit, total protein, WBC, neutrophil count, urea, ALT, ALP, GGT and urinary density worsened during treatment $(P \leq 0.05)$. However, no correlation between those parameters and survival time was verified.
The statistical results indicated that none of those evaluated parameters may be used as a prognostic marker when the animals come for the first consultation.

\section{Conclusion}

Canine cutaneous lymphoma is associated with a poor prognosis due to its poor response to therapy, early relapse and short survival time, as confirmed in this study.

The use of lomustine at $90 \mathrm{mg} / \mathrm{m}^{2}$ as a monotherapy in the treatment of canine cutaneous lymphoma showed moderate efficacy, leading to partial remissions in more than half of the dogs of this study; however, important deleterious effects were noted, especially anorexia, vomiting, diarrhea, myelosuppression, and liver and kidney toxicity, worsening the clinical presentation and prognosis of the affected animals.

These results are relevant and highlight the importance of further studies to establish a better therapeutic approach and determine prognostic markers for canine cutaneous lymphoma.

\section{Conflicts of interests}

The authors declare no interest, financial or relationship conflicts with other people or organizations that could inappropriately influence their work.

\section{Acknowledgement}

The authors acknowledge CAPES for the master's degree scholarship, and FAPESP for financial support (process number 2010/15928-0). 


\section{References}

ALMEIDA, V. L.; LEITÃO, A.; REINA, L. C. B.; MONTANARI, C. A.; DONNICI, C. L.; LOPES, M. T. P. Câncer e agentes antineoplásicos ciclo-celular específicos e ciclo-celular não específicos que interagem com o DNA: uma introdução. Química Nova, v. 28, n. 1, p.118-129, 2005. doi: http://dx.doi.org/10.1590/S0100-40422005000100021.

FLORY, A. B.; RASSNICK, K. M.; AL-SARRAF, R.; BAILEY, D. B.; BALKMAN, C. E.; KISELOW, M. A.; AUTIO, K. Combination of CCNU and DTIC chemotherapy for treatment of resistant lymphoma in dogs. Journal of Veterinary Internal Medicine, v. 22, n. 1, p. 164-171, 2008. doi: http:/dx.doiorg/10.1111/j.1939-1676.2007.0005x.

FONTAINE, J.; BOVENS, C.; BETTENAY, S.; MUELLER, R. S. Canine cutaneous epitheliotropic T-cell lymphoma: a review. Veterinary and Comparative Oncology, v. 7, n. 1, p. 1-14, 2009. doi: http//dx.doiorg/10.1111/j.1476-5829.2008.00176x.

FONTAINE, J.; HEIMANN, M.; DAY, M. J. Canine cutaneous epitheliotropic T-cell lymphoma: a review of 30 cases. Veterinary Dermatology, v.21, p.267-275, 2010. doi: http://dx.doi.org/10.1111/j.1365-3164.2009.00793.x

FOURNEL-FLEURY， C.; PONCE， F.; FELMAN， P.; BLAVIER, A.; BONNEFONT, C.; CHABANNE, L.; MARCHAL, T.; CADORE, J. L.; GOY-THOLLOT, I.; LEDIEU, D.; GHERNATI, I.; MAGNOL, J. P. Canine T-cell Lymphoma: a morphological, immunological, and clinical study of 46 new cases. Veterinary Pathology, v. 39, n. 1, p. 92-109, 2002. doi: http://dx.doi.org/10.1354/vp.39-1-92.

HAUCK, M. L. Tumors of the skin and subcutaneous tissues. In: WITHROW, S. J.; VAIL, D. M.; PAGE, R. Small animal clinical oncology. Missouri: Elsevier Health Sciences, 2013. p. 305-320.

HEADING, K. L.; BROCKLEY, L. K.; BENNETT, P. F. CCNU (lomustine) toxicity in dogs: a retrospective study (2002-07). Australian Veterinary Journal, v. 89, n. 4, p. 109-116, 2011. doi: http://dx.doi.org/10.1111/j.17510813.2011.00690.x.

HOSOYA, K.; LORD, L. K.; LARA-GARCIA, A.; KISSEBERTH, W. C.; LONDON, C. A.; COUTO, C. G. Prevalence of elevated alanine transaminase activity in dogs treated with CCNU (Lomustine). Veterinary and Comparative Oncology, v. 7, n. 4, p. 244-255, 2009. doi: http://dx.doi.org/10.1111/j.1476-5829.2009.00197.x.
JACOB, F.; POLZIN, D. J.; OSBORNE, C. A.; NEATON, J. D.; KIRK, C. A.; ALLEN, T. A.; SWANSON, L. L. Evaluation of the association between initial proteinuria and morbidity rate or death in dogs with naturally occurring chronic renal failure. Journal of the American Veterinary Medical Association, v. 226, n.3, p. 393-400, 2005. doi: http://dx.doi.org/10.2460/javma.2005.226.393.

KANEKO, J. J.; HARVEY, J. W.; BRUSS, M. L. Clinical biochemistry of domestic animals. $6^{\text {th }}$ ed. San Diego: Academic, 2008. 916 p.

KRISTAL, O.; RASSNICK, K. M.; GLIATTO, J. M.; NORTHRUP, N. C.; CHRETIN, J. D.; MORRISONCOLlister, K.; COTTER, S. M.; MOORE, A. S. Hepatotoxicity associated with CCNU (Lomustine) chemotherapy in dogs. Journal of Veterinary Internal Medicine, v. 18 , n. 1, p. 75-80, 2004. doi: http://dx.doi.org/10.1111/j.1939-1676.2004.tb00138.x.

LORIMIER, L. P. Updates on the management of canine epitheliotropic cutaneous $t$-cell lymphoma. Veterinary Clinics: Small Animal Practice, v. 36, n. 1, p. 213-228, 2006. doi: http://dx.doi.org/10.1016/j.cvsm.2005.09.013.

MOORE, P. F.; OLIVRY, T. Cutaneous lymphomas in companion animals. Clinics in Dermatology, v. 12, n. 4, p. 499-505, 1994. doi: http://dx.doiorg/10.1016/0738-081X(94)90216-X.

POLZINI, D. J. Investigating proteinuric kidney disease. Veterinary Medicine, v. 102, n. 12, p. 784-785, 2007.

RASSNICK, K. M.; MOORE, A. S.; WILLIAMS, L. E.; LONDON, C. A.; KINTZER, P. P.; ENGLER, S. J.; COTTER, S. M. Treatment of canine mast cell tumors with CCNU (Lomustine). Journal of Veterinary Internal Medicine, v. 13, n. 6, p. 601-605, 1999. doi: http://dx.doi.org/10.1111/j.1939-1676.1999.tb02217.x.

RISBON, R. E.; LORIMIER, L. P.; SKORUPSKI, K.; BURGESS, K. E.; BERGMAN, P. J.; CARRERAS, J.; HAHN, K.; LEBLANC, A.; TUREK, M.; IMPELLIZERI, J.; FRED III, R.; WOJCIESZYN, J. W.; DROBATZ, K.; CLIFFORD, C. A. Response of canine cutaneous epitheliotropic lymphoma to lomustine (CCNU): a retrospective study of 46 cases (19992004). Journal of Veterinary Internal Medicine, v. 20, n. 6 , p. 1389-1397, 2006. doi: http://dx.doi.org/10.1111/j.19391676.2006.tb00756.x. 
SILVIA, M. P. N. Síndrome da anorexia-caquexia em portadores de câncer. Revista Brasileira de Cancerologia, v. 52, n. 1, p. 59-77, 2006.

SKORUPSKI, K. A.; HAMMOND, G. M.; IRISH, A. M.; KENT, M. S.; GUERRERO, T. A.; RODRIGUEZ, C. O.; GRIFFIN, D. W. Prospective randomized clinical trial assessing the efficacy of Denamarin for prevention of CCNU-induced hepatopathy in tumor-bearing dogs. Journal of Veterinary Internal Medicine, v. 25, n. 4, p. 838-845, 2011. doi: http://dx.doiorg/10.1111/j.1939-1676.2011.0743x.
VETERINARY cooperative oncology group - common terminology criteria for adverse events (VCOG-CTCAE) following chemotherapy or biological antineoplastic therapy in dogs and cats v1.1. Veterinary and Comparative Oncology, p. 1-29, 2011. doi: http:/dx.doiorg/10.1111/j.14765829.2011.00283x.

WILLIANS, L. E.; RASSNICK, K. M.; POWER, H. T.; LANA, S. E.; MORRISON-COLLISTER, K. E.; HANSEN, K.; JOHNSON, J. L. CCNU in the treatment of canine epitheliotropic lymphoma. Journal of Veterinary Internal Medicine, v. 20, n. 1, p. 136-143, 2006. doi: http://dx.doi.org/10.1111/j.1939-1676.2006.tb02833.x. 